\title{
11 \\ ADVISERS? ACTIVITIES BEYOND THE BATTALION
}

\author{
Ron Boxall and Ron Bade
}

\section{Introduction by Robert O’Neill}

In taking part in the Vietnam War we were aware that once again Australia was providing a small contingent in a major conflict which our principal allies regarded as very important. We had played a similar role in the Second World War and the Korean War. We thought it very likely that Australia would be called upon to give similar service and support in future conflicts in this region, under US leadership. Therefore, we, as soldiers, wanted to test the effectiveness of our alliance partnership at the ground force level. We were keen to have direct personal experience of how it worked, and to draw our own conclusions for the future from a year of operating together.

Soon after 5th Battalion, the Royal Australian Regiment (5 RAR), had settled into its final perimeter within the newly established 1st Australian Task Force (1 ATF) base at Nui Dat, the battalion was required to provide personnel for tasks which were well beyond our normal range of responsibilities. One of our officers was detached to work with a CIA-sponsored activity and, later, another was detached to be an adviser to a South Vietnamese Army Regional Force company transferred from the Saigon area. The activities of both elements were confined to Phuoc Tuy Province, within 10 kilometres of 1 ATF's base at Nui Dat. Captains Boxall and Bade each describe their experiences and thoughts on these activities in this chapter. 


\section{Ron Boxall}

In mid-to-late July 1966 I was going about my chores as second in command (2IC) of D Company, 5 RAR. Our company base within the 1 ATF perimeter at Nui Dat was on the upper eastern slopes of the Nui Dat hill feature. We were geographically separated from the rest of the battalion and in the enviable position of not being sited on the more vulnerable parts of the 1 ATF base perimeter. I suppose this was how I came to be selected as more readily available than others for a job detached from 1 ATF.

For a young temporary captain, the experiences I was about to have would prove intriguing, eye-opening and quite instructive. Despite any seemingly sour notes in the following paragraphs, I would not have missed the sojourn at any price. Its many lessons were pure gold.

My recall of dates throughout the period I describe is clouded because I didn't keep a diary, and second, the day-to-day activity of the group to which I was assigned wasn't required to be reported to Headquarters 1 ATF (HQ 1 ATF). From the start of my detachment from 5 RAR I maintained a radio on 1 ATF's command radio net, but I was never fed any information by it or required to furnish details of my day-to-day activities. On the few occasions when I offered information I thought was pertinent, my efforts drew what I took to be a mixture of confusion and indifference. So, I desisted, resolving to maintain radio communications to report only incidents of pressing operational importance and to ensure that I had a means of calling for artillery fire support. I seemed to be regarded as something of a wild card who was monitoring the 1 ATF command net to keep myself in the picture about what was going on around me. Thus, most details of my activities were not recorded either by myself or in the 1 ATF radio log. In retrospect I think that I was considered as working for an obscure foreign agency to whom my activities were of immediate importance and from which any relevant intelligence and other information would filter to 1 ATF through the US Phuoc Tuy provincial headquarters. Crazily, I had no means of communicating with my American civilian 'boss' in Ba Ria other than by visiting him; a one-way arrangement in that my visits were never reciprocated. 
The events that followed gave me an insight into the pseudo-military shenanigans which some of our American allies seemed to hold in great store. I accept that there were probably some 'sneaky-Pete' triumphs they could claim, but my experiences of them left me with the conclusion that the results of such activities in Phuoc Tuy in the early days of 1 ATF's operations were quantifiable only in the negative. I have since concluded that, apart from insisting that a 1 ATF officer be assigned to a CIA intelligence operation in Phuoc Tuy, the commander of 1 ATF probably had no say in the presence or activities of a 'Combined Studies Group' (CSG) operation within his bailiwick; CSG being one of the flimsy noms de guerre used by the CIA during the Vietnam War. Additionally, it soon became clear to me that those directing the CSG were not happy with the arrangement which inserted an outsider into their cabal. Inevitably, I developed the view that its ongoing activities in the province had more to do with the preservation of US intelligence agency fiefdoms than being a seriously considered part of prosecuting the local shooting war. The concept of CSG efforts in Phuoc Tuy Province was arcane and its hard-toglimpse rationale seemed little more than delusive chicanery-less macabre, but similar in mentality to the US military's lamentable predilection for inflating enemy body counts throughout the Vietnam War.

I left 5 RAR to report to HQ 1 ATF, awash with confidence that I would receive a detailed briefing and accompanying orders but was simply told that I was to replace another 1 ATF officer currently 'running' a Vietnamese 'outfit' presently located in the large village of Hoa Long, which was noted for the mixed loyalties of its inhabitants. It was the capital of Long Le district and located astride Route 2 between 1 ATF's base at Nui Dat and the provincial capital, Ba Ria. I was to contact this officer and he would brief me. I soon located him and his small team of three Australians, whom I will describe shortly.

Meeting him and seeing his 'headquarters', located in a disused schoolhouse roughly in the centre of Hoa Long, did little for my enthusiasm for what might lie ahead. The man I was to relieve was also a 1 ATF infantry captain who appeared slightly older than me. Surprisingly I did not know him, nor had I ever heard of him. He was a thin, sallow-complexioned man with a narrow, Hollywood-hero moustache. He sported a standard army bush hat which had been starched and carefully shaped into a version of a civilian pork-pie hat, which he wore perched squarely and set low on his brow. He had the appearance of a minor Damon Runyon character rather like a fugitive from a race course betting ring. His general manner 
and lack of enthusiasm conveyed that he was not impressed with his current circumstances and was much looking forward to putting them behind him.

His 'briefing', though reasonably comprehensive, was unstructured and delivered mostly by responding to my queries or prompts by his team members. He thus conveyed that the non-ARVN (Army of the Republic of Vietnam) company-sized unit was recruited, equipped and paid by the CSG's chief agent in Phuoc Tuy Province who operated from Ba Ria. In effect they were civilians; a mixture of Nungs (Vietnamese Chinese) and Montagnards (aboriginal people from Vietnam's mountainous regions). Allegedly both groups had a deep-seated dislike of the Vietnamese. By joining this CSG program they were absolved from service in the ARVN and were paid more than their ARVN counterparts, but there was no rank structure as such. Their leaders at company, platoon and squad levels were described as having been elected by their peers and received a pay-loading for the honour. There were no apparent disciplinary arrangements or clear means of enforcing rules or orders other than the threat of dismissal. For the most part they were dressed in elaborately patterned camouflage uniforms and armed with a variety of weapons, many of which were of non-US origin. They sported berets with a badge depicting a rearing cobra and most wore M26 hand grenades on the chest straps of their equipment, while carrying about them a range of other military and civilian items which gave the appearance of an armed flock of itinerant hoarders. They were currently scattered in small groups among Hoa Long's many houses, supposedly as a deterrent to Viet Cong movement in and out of the very large village. There being no radio communications within the group, the only method of internal communication was by gatherings of platoon and squad 'leaders'. The senior member or 'company commander' was described as a mere figurehead who nodded wisely as instructions, all devised and coordinated by the 'advisers', were imparted.

The group went by two names. Depending on the speaker's preference, they were variously referred to as 1 Commando Company (1 Cdo Coy) or the Provincial Reconnaissance Unit. In other words, whichever took your fancy would do. In this narrative I will stick to 1 Cdo Coy which seemed to be the 1 ATF preference. At the completion of his 'briefing' my predecessor departed with a flippant farewell to me and his former team members, which we returned in kind. My new colleagues soon made it clear that they regarded his replacement as a relief in more than one sense of the word. 
The small team of 'advisers' I was to head consisted of two Australian Army Training Team (AATTV) warrant officers (WO), Alan Seale and 'Squizzy' Taylor, and a Vietnamese linguist from HQ 1 ATF, Corporal 'Bondi' Bailey. Alan proved to be a crusty, no-nonsense Englishman with many years of service as an Australian infantryman. Squizzy was a steady ordnance WO having his first experience of more warriorlike duties. Both became great backstops for me and relieved many uncertainties with their wise counsel, versatility and remarkable adaptability. Bondi Bailey was another great operator; steady, reliable and a very accomplished interpreter.

The district chief, Dai Uy (Captain) Kim, had his district headquarters in Hoa Long but it proved hard to arrange a meeting with him until an incident occurred which caused our paths to cross, when he demonstrated that he was both perceptive and a man of action. He was very unhappy with the presence of 1 Cdo Coy in his district capital and had been so since they were first thrust into his domain. He claimed to have no say in their presence or their activities which were disruptive and resented by all villagers, irrespective of their political loyalties. By the time I met Kim this resentment had already become apparent to me through observing the clearly poor relations between the villagers and $1 \mathrm{Cdo}$ Coy personnel. This seemed largely related to the pestering of village women, boozy behaviour and chicken rustling. I'm sure that the villagers' resentment included a strong element of fear of these interlopers.

A week or so after my arrival in Hoa Long a short succession of shots came from the village market place not far from our schoolhouse. Grabbing our weapons, we moved around the intervening houses to the market place where we found a relatively calm gathering of villagers milling around something which was holding their attention. Moving cautiously through the throng we met Kim and his adviser, a US Army captain. Both were armed with M16 rifles and before them lay the body of one of 1 Cdo Coy's members. Kim explained that the dead man had been drunk and threatening villagers with his weapons. He had been summoned to the scene and, after assessing the problem, applied his long-held policy of never arguing with a heavily armed drunk and promptly shot him. After we recovered the man's weapons and ammunition, Kim arranged the disposal of his body. The man's demise didn't seem to affect his comrades unduly; the villagers remained impassive. Clearly all had become inured to witnessing the swift justice which often went with the overt authoritarianism commonly practised at the lower levels of the South 
Vietnamese government. When I reported the loss of this man to my CSG 'boss' it was dismissed with a verbal shrug and the conversation moved on to other matters.

This brings me to a description of how my interaction with the CSG in Phuoc Tuy Province played out. Immediately following the departure of my predecessor, I visited my 'boss' in his villa headquarters in Ba Ria. His name was Mathews and he claimed to be a former corporal in the US Marine Corps. He basically confirmed what my predecessor had told me. Throughout our conversation he was either unsure of the rationale behind the presence of 1 Cdo Coy in Phuoc Tuy or was being clumsily guarded about it. When I asked what type of operations they had been trained for, he became quite vague and spoke in circles about infiltration of Viet Cong village infrastructure and its subsequent elimination. Experience and events soon revealed that, apart from some basic weapons training, evidence of realistic training to those ends was not to be found. Apparently connected with his headquarters were three AATTV members, one captain and two WOs, who were unmistakeably reticent about conversing with me. It was never revealed to me exactly what they did, and I was left to speculate about their role. Their combined attitude and attire excited mild disdain. They were dressed in civilian clothes, with shirts tantalisingly unfastened at the top few buttons, and at hip level they wore low-slung leather holsters emblazoned with the bold letters 'US' and containing ubiquitous Colt .45 calibre automatic pistols. One of the WOs was overweight and looked particularly comical.

A short time afterwards I was advised that Mathews had been replaced so I went to Ba Ria to meet my new 'boss'. To the best of my memory his name was Buckley and he claimed to be a former US Army lieutenant colonel. He was a taciturn man who gave the impression that he had been sent in as a new broom to tidy up the local CSG operation. His first task for me was to fire a third of the 1 Cdo Coy's members and recover their weapons. On my return to Hoa Long our small team burned the midnight oil to devise a scheme for what might prove to be a very delicate administrative manoeuvre.

Our plan was simple and worked smoothly. We were to kick things off on the next pay day, beginning with an assembly parade in front of the school house which contained a few separate but interconnected rooms. The members were told that all weapons, ammunition and equipment were to be checked for serviceability or replacement on pay day. They 
were told to deposit their present weapons, ammunition and equipment in a large room at the end of the building via an external door and return to the 'pay parade' in front of the school house, and that payment would commence when this was completed. When all had complied, the large room was made secure and payment was commenced with individuals entering the pay room one at a time. The pay room was connected by doors to two other large rooms. After being paid, each of those who had been selected for retention were directed into one of the adjoining rooms and the 'discards' were directed to the other. Both groups were to remain in these rooms until pay was completed.

When all had been paid, the discards were released into the custody of Kim's ARVN soldiers who arranged their rapid removal from Hoa Long. The 'keepers' were then reissued with their weapons, ammunition and equipment, and organisational adjustments and reassignments to tasks were made. The operation was completed by returning most of the recovered weapons to CSG. Recovered ammunition and equipment items were retained as an immediate resupply pool. The reaction of the 'keepers' to dismissal of the 'discards' seemed to be one of general indifference - but, after all, they still had their jobs. I later heard that such rationalisations were an occasional feature of life in the employ of CSG in Phuoc Tuy Province. This must have been an ongoing depletion of the certitude and morale of 1 Cdo Coy's members, not to mention their loyalty.

After a few weeks at Hoa Long, 1 Cdo Coy was redeployed to the village of Binh Ba which was located on Route 2, some 7 kilometres north of the 1 ATF base at Nui Dat. No reason was given for the change of location, but their task remained to deter Viet Cong movement in and out of Binh $\mathrm{Ba}$ village, which was quite a different situation from Hoa Long. It was the location of a French-owned rubber plantation and processing factory. The operation's business name was Don Dien de Gallia. The village was adjacent to the factory and consisted of well-arranged, substantial dwellings for housing the factory employees and plantation workers. A fine Roman Catholic Church was a part of the village and it was served by a very canny, diminutive, French-educated priest called Pere Joseph. Slightly apart from the village and near the factory were a pair of large two-storeyed villas which housed two Frenchmen, the operation's manager, Jean-Jacques Pernes, and its engineer, Monsieur Moreau. A couple of hundred metres to the north of the village a large grass airfield extended 2,000 metres westwards from a satellite hamlet, Ap Ngai Giao, also located on Route 2. About a third of the way along its length, on its northern side, there was another villa which was unoccupied. Pernes and 
Moreau both spoke Vietnamese and I communicated with them in that language through Bondi Bailey. A short time later, a French-born soldier from 5 RAR, Private Ron 'Frenchy' Delaurey-Simpson, joined our team to provide another avenue of communication.

It was clear that Pernes and Moreau did not want $1 \mathrm{Cdo}$ Coy personnel living around the village houses as they had done in Hoa Long. Their reputation had probably preceded them. Instead, I had the use of the villa beside the airstrip and the 1 Cdo Coy 'troops' were deployed to its north in the adjacent rubber plantation. From there they went about various minor tasks associated with being a 'deterring presence'. Determining their tasks was complicated by the certainty that most of them couldn't be trusted out of sight; and it was not long before problems like those experienced at Hoa Long re-emerged. I had been told that the sudden redeployment from the Long Le district capital to this commercial operation's workers' village in Duc Thanh district was done at the request of the Phuoc Tuy province chief, Colonel Dat. In response to my queries, the upbeat yet slightly evasive way in which this information was confirmed by my usually taciturn CSG 'boss', Buckley, led me to suspect that there was more to the story. Subsequent events were to reinforce my suspicions.

One day a light aircraft landed on the village airstrip and taxied to the western end of Binh Ba, opposite 'my' villa. With some flying experience and a keen interest in light aircraft I recognised it as a Helio Courier, a relatively rare and highly capable American short take-off and landing aircraft. As I drove towards where the aircraft was parked I noted that it was unpainted and had no markings apart from a black serial number on the tail fin. As I got closer I saw that it had 'AIR AMERICA' in quite small letters on the side of the fuselage, just behind the wings. As I arrived near where it had parked, Pernes and Moreau also arrived in their small Citroen CV2. Two civilians wearing sidearms emerged from the aircraft and, after cursory nods to me, one of them engaged Pernes and Moreau in conversation in Vietnamese. Bondi Bailey wasn't with me and I could not follow what was said. After a short time, a tightly packed bundle, approximately $30 \times 30 \times 30$ centimetres in size and neatly tied with some sort of binding wire or cord, was transferred from the aircraft to the Citroen. From about six or seven metres it looked to me like paper money. With nothing further said, and nods all round to me, the Frenchmen and the Americans departed in their respective machines. Assuming CSG would be aware of their Air America confreres' activities I thought no more about it until two days later when Pernes approached me. He asked 
whether I knew of any artillery tasks that might be fired during the next day or so to the north along Route 2 towards the Courtenay rubber plantation. I replied that I was not permitted give him any details of operational matters. He readily accepted my reply and I asked why he wanted to know such things. He replied, quite matter-of-factly, that he needed to go north along Route 2 to a rendezvous (with the Viet Cong) where he would 'pay the next of his company's "tax" instalments' which allowed its operations to continue unmolested. I knew it would be pointless to ask him to provide more details as it would be inviting him to possibly compromise himself and his workers. It was left for me to ponder why the CIA was delivering money to be paid to the Viet Cong via a French rubber plantation operation. I suspect the real answer would have been both mind-boggling in its complexity and deliciously absurd in its rationale.

At one point a jeep with three US Army communications specialists arrived unannounced to stay for a few days. They described themselves as a 'radio research team' whose equipment was used to obtain fixes on enemy radio locations. They were emphatic about removing their signals equipment, documentation and weapons from their vehicle and securely stowing them inside the villa but left numerous items in the unattended jeep. Some of these were promptly liberated by untraceable elements of 1 Cdo Coy. The new arrivals were particularly upset about the loss of some bourbon whisky, their other missing items being of comparatively small concern. Their marked attention to the security of their radio equipment seemed curious considering they were tasked to swan about the countryside in their lone-runner jeep, obviously prone to ambush and loss to the enemy of their sensitive equipment, not to mention their lives. Their parent organisation was obviously comprised of deep thinkers.

Around this time, I received a message from 1 ATF that Land Rover spare parts were in short supply. I was to return my Australian Army vehicle as soon as possible and should approach my CSG 'boss' about supplying me with another vehicle before I relinquished the Land Rover. I did so, and he gave me a completed US Army requisition form and told me to submit it to the US Army cannibalisation point at Cat Lo near Vung Tau where I was told to come back in a week's time and a jeep would be put together for me. When I returned, the non-commissioned officer (NCO) attending to me required a receipt for the 'bitzer' M38 A1 jeep. I was unsure of all the implications but, being an admirer of Major Stan Maizey's dubious but effective acquisition techniques, I supplied a signature; not my own, 
but a signature indeed. The NCO didn't care - he had a signature and was not interested in my bona fides. On the way back to Binh Ba I dropped off the Land Rover at 1 ATF, where I had its .30 calibre Browning machine gun and its mounting transferred to the jeep, before making my way back to Binh Ba.

Phase 1 of 5 RAR's Operation Holsworthy was a very successful cordon and search of Binh $\mathrm{Ba}$ on the night of 7/8 August 1966. Following the cordon and search, as I described earlier, 1 Cdo Coy was moved from Hoa Long to the area of the villa by the airfield at Binh Ba, while 5 RAR continued with Operation Holsworthy in and around Binh Ba. In his Commander's Diary for August, Brigadier Jackson 'propose[d] to maintain a [5 RAR] rifle company with sections of mortars and APCs [armoured personnel carriers] at Binh Ba until [he was] satisfied that the Province Chief can assure the security of the place'.

On 17 August the 1 ATF base at Nui Dat was mortared and Operation Holsworthy was terminated, with all elements of 5 RAR except C Company returning to Nui Dat. On the following day, 18 August, the Battle of Long Tan took place some 8 kilometres to our south-east. I and my small team listened intently to the 1 ATF command net throughout these events. Should the Viet Cong elements involved at Long Tan have moved in our direction, our survival plan was based on the reasonable belief that $1 \mathrm{Cdo}$ Coy would decamp at the first hint of trouble. Fortunately, the enemy survivors of Long Tan retired in other directions and our self-extraction plan was shelved.

Over 50 years later I became aware of a 5 RAR operation order for Operation Woolloomooloo which is dated 17 August 1966, the day before the Battle of Long Tan. It was clearly prepared in haste as it was signed by Major Bert Cassidy and not 5 RAR's operations officer Major Max Carroll, who would have been flat out with other very pressing priorities as the first major Australian engagement of the war was unfolding. The purpose of Operation Woolloomooloo was to fulfil the Commander 1 ATF's diarised intention to maintain a rifle company with mortars and APCs (armoured personnel carriers) at Binh Ba on a rotation of seven to 10 days until the province chief could provide a suitable ARVN presence there. The operation order's mission paragraph reads, 'The 5RAR rifle company is to provide support to $1 \mathrm{Cdo}$ Coy at Binh Ba'. In its 'friendly forces' paragraphs it details 1 Cdo Coy's tasks at Binh Ba, none of which I had heard either formally or fully expressed 50 years earlier from any 
source. It also stated that ' 1 Cdo Coy operates through an Australian adviser and is under the tactical control of 5RAR'. These and many other revelations were contained in this operation order which I saw for the first time in late 2017 while checking facts for this narrative. With some bemusement and annoyance, I looked at its Distribution List and found that neither CSG, 1 Cdo Coy nor I appeared as recipients of any of its 70 copies.

5 RAR's operational files show that, following Operation Holsworthy, C Company remained in the vicinity. It was listed as the first of 5 RAR's rifle companies undertaking the rotation at Binh $\mathrm{Ba}$ from 23 August to 14 September, followed by A, B and D Companies until 4 October, when Operation Woolloomooloo concluded prior to the commencement of Operation Canberra in the Nui Thi Vai hills on 6 October. At no stage of my sojourn at Binh Ba was there any mention of an operation codenamed Woolloomooloo. It is interesting to note that it is not mentioned in the official history nor in Bob O'Neill's Vietnam Task. Understandably, the operation order was probably prepared in haste then de-prioritised and somewhat forgotten in the turbulence of Long Tan and its aftermath. It was to remain unmentioned by any recorder of 1 ATF's early history in Phuoc Tuy Province.

Shortly before Operation Woolloomooloo concluded, I was advised that 1 Cdo Coy was to be removed from Binh Ba and returned to CSG's fold for employment elsewhere. I was not given any reason for its withdrawal, but it was obvious to all that its effectiveness was non-existent, and its presence was disruptive. On the day before its withdrawal I was recalled to 5 RAR to be involved in Operation Canberra, commanding the defence component of a 103 Field Battery gun position beside Route 15 near Ap Ong Trinh Dp. My obvious means of movement was the jeep in my possession, so I drove it to Nui Dat, accepting that I might have to surrender it subsequently.

On my return to 5 RAR I made the mistake of driving through battalion headquarters on my way to D Company when I caught the eagle eye of Stan Maizey. Obeying his firm indication to pull up beside him I was confronted by his best quizzical and covetous scowl. "Where did you get this?' was his opening gambit. I gave him the details. His response was, 'Well, I'll be having it!' I said, 'No sir!' He said, 'What? Come again!' I said, 'No sir - I scrounged it fair and square!' His frown softened, the corners of his mouth curved into a wisp of a smile and, with the merest 
hint of admiration, he conspiratorially asked, 'Can you get any more?' To his clear disappointment the gist of my reply was, 'Unlikely'. Next day he sent a message to D Company, 'In view of the scarcity of spare parts, and with the advent of Jack 1 [the jeep's new nickname], D Company is to return one of its two Land Rovers to the Battalion vehicle pool'. Stan was a hard man to beat - but he did like a trier. The jeep postscript is that I was never asked to surrender it and, when D Company left Nui Dat to occupy the Horseshoe hill feature 7 kilometres south-east of Nui Dat, it was bequeathed to the chaplains who usually had to cadge lifts to go about their ministrations.

Although the term was never used, I later presumed that 1 Cdo Coy may have been an experimental part of the so-called 'Phoenix Program' which was supposed to target and eliminate the Viet Cong infrastructure (VCI) at village level. In the American television series The Vietnam War, made in 2017, Tran Ngoc Chau, the South Vietnamese progenitor of the Phoenix (Phung Hoang) Program, spoke briefly. He disappointedly described it as 'his teenager who went astray and was lost to his foster parents' (the CIA?).

The Phoenix Program was rated poorly in the television series, with only a brief negative mention of it as an 'assassination and torture program'. Brigadier Chamberlain, the author of Appendix D, noted in January 2018:

My experience of Phoenix when working in the Phuoc Tuy Provincial Intelligence Operations Centre in 1969, was that it was ineffectual due partly to distrust and little cooperation between the 'competing' agencies.

He also noted that, as late as June 1970, 1 ATF reports assessed that the Phoenix Program:

achieved very few results ... there had been a reduction in the VCI (Viet Cong Infrastructure) resulting from 1ATF ambushes, contacts, air strikes and Hoi Chan (defectors), but remarkably little that can be attributed to the Phung Hoang (Phoenix) Program ... Most VCI eliminations are a direct result of 1ATF operations, identification of VCI personnel from captured documents, defectors and prisoner of war interrogations ... Few of those eliminated have been important cadres at village level, most being low level supply organizers ... The (Allied) intelligence community is fragmented and uncoordinated. 
Towards the end of Chapter 5, Bob O'Neill gives an insight into the jealousies and rivalries at play among and between the intelligence and operations staff of US military headquarters at various levels. One can only imagine, with some incredulity, what the relationships between the military intelligence communities and the US 'spook' agencies must have been like - somewhere between feigned and non-existent? In their military doctrine the Americans subscribe to nine principles of war. One of them, unity of command, is described as having the purpose of 'ensuring unity of effort under one responsible commander for every objective'.

Why then did the commander of 1 ATF, who had the overall objective of defeating the Viet Cong in his assigned area of operations, need to endure quasi-military activities by non-military US agencies, together with the presence of loosely controlled ARVN elements within areas in which he was conducting operations without having at least temporary control over them? An ARVN artillery incident during Operation Robin, which is described by George Bindley towards the end of Chapter 12, illustrates both the perils and diseconomies of not addressing this need. Such issues raise obvious questions about why peripheral CIA intelligence activity with its associated quasi-military operations needed to be sequestered from the primary military effort, and why inability or failure to coordinate effectively all contributions to warfighting at the operational and tactical levels seemed to pervade the way in which the Vietnam War was conducted.

The resulting confusion was exacerbated by the cynical obfuscation that the Government of South Vietnam was in command of the war, supported by allies, principally the United States. No amount of window dressing could conceal that it was America's chosen war and that her military were directing its operations, albeit alongside an apparently separate battlefield involvement of the CIA.

Our American friends might say that poor ARVN reliability imposed an imperative need for strict adherence to other US principles of war, like security and surprise, which outweighed need for unity of command. Perhaps so, but the routine, continual sidelining of any fundamental principle is a form of fraudulent self-deception. It is often held that fraud is a virtue in war; but only when it is practised against the enemy and not allowed to become a delusory and energy-consuming internal malady. 
While reflecting on the broader Vietnam War during the many months of this book's gestation, I came across a commentary in the Time magazine issue for 9 April 2018. It was written by Admiral James Stavritis, US Navy, a former supreme allied commander of NATO. He drew attention to a book, Dereliction of Duty, by Lieutenant General HR McMaster, US Army. Published in 1997, it was based on a very highly rated doctoral thesis which McMaster had prepared as a major and graduate student at the University of North Carolina. Dereliction of Duty became a bestseller and has been studied in many US military colleges and research institutes. In his comments, Admiral Stavritis opined that:

Dereliction of Duty is in many ways a stinging indictment of the Washington culture of deceit, hidden agendas and backstabbing that helped pull the US into a quagmire in Vietnam. It tells the story of the malfeasance of the uniformed senior military in misleading the nation and the President about the true state of affairs as the war spiralled down to defeat. ${ }^{1}$

The propagation and scattering of 'private armies', inimically discrete intelligence operations and loosely controlled ARVN elements among overarching military operations without responsibility for overall command, control and coordination being vested in one military commander at each appropriate level was bound to become nugatory. There is much to question about why the CIA was not confined to clandestine activity elsewhere than on the battlefield, and denied any right to meddle thereon. Mine was only a brief exposure to one of the CIA's widespread, tacked-on warfighting schemes; one which seemed to lack definition, credible reputation or incisiveness. During a second tour of duty five years later, again with an RAR battalion, I perceived no changes to what by then had become a stalled formulaic prosecution of the broader war. Thus, the Vietnam War stands as a beacon of political and military failure to adapt and revise failing strategy.

Before concluding, I should not forebear from rating the peripheral and puny 1966 contributions to warfighting within Phuoc Tuy province by 1 Cdo Coy and its parent organisation. In the interests of brevity and clarity I borrow the incomparable pragmatism of the Australian digger to say, 'The whole idea was about as much use as tits on bacon - zero out of ten!'

1 James Stavridis, 'H.R. McMaster worked for me: His retirement from the military reveals a lot about President Trump', Time, 9 April 2018, available at: time.com/5212570/hr-mcmaster-trump/. 
I was to be followed later at Binh Ba by a fellow 5 RAR officer, Captain Ron Bade, whose experiences are related in the following section of this chapter. His circumstances were different to mine and neither of us became aware of each other's time at Binh Ba until many months had passed. Nonetheless, both of us drew conclusions early in our separate experiences that there was a need for astute caution when working at the lower level of US - South Vietnamese relations in Phuoc Tuy Province.

\section{Ron Bade}

My one big regret about my time in Vietnam was that I did not keep a diary. For some reason I thought that keeping a diary with reference to operations would be a security risk. Now, as I sit and attempt to recall the events of more than 50 years ago, my one thought is, 'If only!' This means that some of my recollections about date/time details and names may not be precise; but I trust that I may be allowed some leeway. When I consider my time at Binh $\mathrm{Ba}$ as a temporary adviser to a Regional Force (RF) company, my only substantive date reference point is that I was there when I received news of my son's birth. He was born on 10 October 1966 and a day or so afterwards a Royal Australian Air Force Iroquois landed on the airfield beside the compound and our CO, John Warr, accompanied by Tony White, Peter Isaacs and Bob O'Neill, jumped out of the helicopter, shook my hand, congratulated me, gave me a copy of the telegram and promptly departed. It was a shame they couldn't have stayed that night as the birth of my son was celebrated with great gusto by the Vietnamese troops. Having a son as first-born is considered very auspicious in Vietnamese culture. The troops expended short air-bursts of small arms fire and coloured flares in lieu of fireworks. My concern that night was that the celebrations would have been a beacon for any enemy operating in the vicinity. Fortunately, nothing happened.

How and when did I get to Binh Ba? I have trawled through the battalion's operations logs as they appear on the Australian War Memorial website and I can find little that indicates dates or the events preceding my moving to Binh Ba. However, looking through the battalion's list of operations, the dates of Operation Darlinghurst or Operation Toledo are the most likely. I was operating the administration cell located forward with battalion $\mathrm{HQ}$, which was harboured in the rubber plantation to the south of Binh Ba. As officer on watch in the APC-mounted command 
post during the night, my signaller received a call from Task Force HQ to 'Fetch Sunray' (John Warr). After speaking with Task Force HQ, John Warr told us of the impending arrival of an ARVN RF company at Binh $\mathrm{Ba}$ the following day. He also said that as advisers from the AATTV were not immediately available, the battalion was to provide a liaison officer (LO) for 48 hours. When I asked who was to be the LO, I was not surprised that it was to be me. At that stage I did not know that my 48 hours was to extend to more than two months!

The next day it struck me that there was a singular lack of communication between the various parties involved in the move of the RF company. What was the mission of the company? If I recall correctly, no formal operation order existed or, if it did, it had not percolated to my level. It seemed that, although Task Force HQ had requested 5 RAR to provide an LO, command of the RF company was to be exercised by the local district chief, Dai Uy (Captain) Nguyen Van Be, based at subsector HQ in Duc Thanh. Also in Duc Thanh was a US Army adviser, Major Bill Prescott, and his team which included US enlisted men and Australian WOs. However, Major Prescott was obviously confined to an advisory role. My team consisted of Warrant Officer 'Sooty' Smith from the Task Force Civil Affairs Unit, a 5 RAR signaller, Private Ron 'Frenchy' Delaurey-Simpson, my batman, a Land Rover with driver and an interpreter, Sergeant Mick Henry (not to be confused with the 5 RAR armourer Sergeant Mick Henrys). My role as an LO was somewhat unclear. Was I simply there for liaison or was I to assume an advisory role? Sooty Smith and I quickly determined that self-preservation dictated that we needed to act as advisers - welcome or not!

When the RF company arrived, I was surprised to see that the soldiers were a pretty rag-tag bunch and that many had arrived with accompanying wives and children. What on earth does one do with wives and children in a defence compound? The company commander, Second Lieutenant Truong, told me that the company had been based not far from Saigon and, being a RF company, it had not expected to be moved out of the district in which it had been raised. Consequently, many of the troops and their families were very upset at moving to Binh Ba. The extent of their upset became very evident during the next couple of days!

The site chosen for the RF company was the vacant villa on the north side of the Gallia plantation airfield on the northern edge of Binh Ba. The site comprised a two-storey masonry villa with a long single-storey building 
behind. I decided that my team would occupy the villa and that the RF company could utilise the other building. This was reluctantly agreed to by Truong. The immediate task was to determine how the company would occupy the site. I discussed the defensive position with Truong and talked about all-round defence and mutual support. However, he was committed to the old, discredited French concept of a triangular redoubt. Despite my remonstrations about his decision, a triangle it was. I thought to myself 'Thank goodness I will only be here for 48 hours!' How wrong was I.

Next morning, I discovered that some of the troops had deserted during the night. I reported this to John Warr and said that the company commander had told me that it would be difficult to prevent further desertions as the troops were very unhappy about the move. Next day, a few more had deserted so John came to the villa in an APC and had me parade the company before him. He spoke through my interpreter telling the RF personnel that anyone else who deserted would be shot. As he spoke, Lieutenant Ross Guymer, in the cupola of his APC, traversed his .50 calibre machine gun back and forth across the assembled company. We had no further desertions!

Forty-eight hours had elapsed and there was no sign of advisers arriving to relieve my team. It was time to discuss roles and routines with Truong. The placement of the company in Binh Ba was obviously designed to deter Viet Cong activity in the village and to provide a measure of protection for the inhabitants. Our first task was to develop the defensive position. Digging weapon pits and a perimeter communication trench commenced, but progress was extremely slow. When we discussed the lack of progress with individuals, the response was always that they were very tired from their move. Of more concern for troops with families was the erection of some form of shelter for their families behind the weapon pits - a novel concept. When it came to daily routine in the position, Truong had little idea of morning or evening stand-to (changing between day and night routines) or the need for clearing patrols to clear the area outside the perimeter. He did agree that he would give this a try, but it was a dismal failure. The chatter from the compound during stand-to was non-stop and the clearing patrols would not venture further than keeping in sight of the compound. 
If our activity extended beyond the compound there was obvious potential for conflict between the RF company and elements of 5 RAR operating at the same time in the Binh $\mathrm{Ba}$ area. Consequently, Task Force HQ gave the RF company a mini-TAOR (tactical area of responsibility) within the Task Force TAOR. This was a large part of the Gallia plantation area north of the airfield. Now, with a defined TAOR, it was my task to get the company out on operations. This turned out to be far more difficult than I expected.

One of the first operations was a cordon and search of a part of Binh Ba village. Truong and I agreed that we would leave our compound and be in place before daybreak. When the day came, the troops milled around the gate of the compound and it was obvious that they had no desire to move out of the compound in the dark. We eventually left the compound as dawn broke. Inevitably, the troops were seen moving into the cordon, so the operation was fruitless. However, Truong was quite excited that they had completed the operation and invited Sooty Smith and me to join his officers and NCOs for a belated breakfast in one of the village food stalls. I can still remember the portions of duck hacked with a cleaver and the splinters of bone therein.

Patrols of our mini-TAOR were pretty much as disappointing as the cordon and search. I had the feeling that the troops had no desire to be outside the compound and they invariably made lots of noise. One wonders if the noise was just ill-discipline or made in the hope that any enemy would hear them and avoid contact. My concern, when I was with them, was that their noise would attract enemy that they were not capable of engaging effectively.

Once I was told that the AATTV advisers would not be coming for some time, we decided to make the old villa as liveable as possible. Our first task was to clear the villa floors of an accumulated ten-centimetre layer of dead black beetles. Happily, we discovered that the toilet on the upper floor would flush by using a bucket of water. The original wooden 'thunder box' latrine that we had purloined from somewhere was no longer useable after troops and their families had 'kangarooed' on the seat with muddy feet! With US steel fence pickets that we obtained from Major Prescott's team, and the help of a welder from the Gallia plantation workshop, we fashioned a frame from which we could suspend a canvas shower bucket. The frame had a base made from pickets that allowed us to shower above 
the mud. We slept on breath-inflated mattresses on the tiled floor. This was quite comfortable, but we did bounce around somewhat when there was a B-52 bombing raid anywhere nearby.

While we were settling in, the company continued to develop our compound. Beyond their original concertina wire obstacle, they built barbed wire fences and then proceeded to lay a minefield of M16 'jumping jack' anti-personnel mines. These were armed and connected to tripwires which would be the undoing of a couple of the troops a short time later. One afternoon I heard several shots from within the compound. They turned out not to be accidental discharges, as had occurred several times already, but were attempts to kill one of the dogs which had strayed in from the Gallia plantation. Two soldiers ran out the front gate of the compound and around the minefield perimeter fence to where an apparently dead dog was laying. As one of them picked up the dog it latched on to one of the men - it was only stunned by the bullet! To get away from the dog, the men ran headlong towards the compound straight into the minefield! Some mines were triggered but, miraculously, both men escaped unhurt. As we watched from the upstairs balcony of the villa, we were dumbfounded.

We were visited quite often by the district chief, Dai Uy (Captain) Be, usually accompanied by some of Major Prescott's team from Duc Thanh. However, information on what was going on around the district was generally scarce. Sooty Smith and I made periodic visits to Messieurs Pernes and Moreau, the manager and engineer at the Gallia plantation, but, although these visits were always cordial, they were of little intelligence value. One got the impression that both men were intent on appearing 'neutral' to be able to carry on business at the plant. As far as information from the Task Force HQ or 5 RAR was concerned, I was kept informed of any plans that might impact my TAOR, but otherwise we were on our own and we felt a bit like the forgotten few. We also visited Father Joseph, the Catholic priest at Binh Ba. He was able to provide limited helpful information on what had been going on in the village, but he was always concerned that he would be branded an informer by local Viet Cong.

Working through an interpreter is always difficult so I knew that I was lucky to have Mick Henry with me. I knew I could guarantee he would tell me what he understood of Be's or Truong's statements, not what a local interpreter might be inclined to pass on - probably what they thought I wanted to hear. Unfortunately, one day Mick said something to Dai Uy 
Be that Be felt was an insult, so he declined to communicate any further through Sergeant Henry. Fortunately, my French-speaking signaller, Ron Simpson, was able to communicate with both Be and Truong in French. This also forced me to resurrect my Year 12 schoolboy French when Be insisted in addressing me in French. Mick Henry, being of no further use, returned to Task Force HQ.

Administrative support from 5 RAR was quite minimal. I resorted to doing a run back to 5 RAR down Route 2 about once a week in my Land Rover, hoping to not run into an ambush. Doing this was a little scary but we were lucky and encountered no problems. We were able to collect clean clothes, pick up our mail and, with the help of the caterer, Warrant Officer Peter Roby, we were able to scrounge rations to keep us alive for another week. It is interesting to note that, during the year after 5 RAR returned home, the AATTV advisers at Binh Ba were ambushed doing the same run as I had done, and I understand that at least two were killed.

Another aspect of the RF company came to light one evening when I was moving around the weapon pits during stand-to. Several families stated that they were very hungry and that they had little or no food. This surprised me as I had seen sacks of rice arriving in the compound and I had seen troops supplementing the rice with fish and greens from the local market as well as plants foraged outside the compound. I raised the issue of hunger with Truong and he informed me that he received the salaries and rice ration for all members of the company and he then distributed both as he saw fit. It was obvious that if any member dissented they were punished with reduced salary or rice ration or both. I said that I felt that restricting rice ration was hardly fair, but my comments fell on deaf ears. Perhaps this was the only real sanction available to him to maintain discipline over his coterie of soldiers and their dependants, but one unlikely to reinforce either his popularity or his personal safety.

Later, I was invited to travel to Sector HQ at Ba Ria with Truong and some of his officers. We braved Route 2 once more with arms bristling out of several vehicles. The conference at Sector HQ gave me the impression that the US advisory staff there were not really interested in the RF and that little was expected of my RF company other than to be a presence at Binh $\mathrm{Ba}$. Following the conference, Truong invited me to his home in $\mathrm{Ba}$ Ria for lunch. I hadn't expected that he would have had a house in Ba Ria - maybe the real reason to visit Sector HQ was to be able to see his wife and family! His home was a modest house, but it was nicely furnished and 
extremely well kept. Lunch was an extremely tasty Vietnamese banquet served by his domestic staff while his troops kept guard outside. On the run back to Binh Ba, I started to wonder about how much of the salary and sustenance moneys entrusted to him went to his troops.

It would be remiss of me to conclude this story without mentioning the disciplinary regime in the company. One day in a corner of the compound some troops built a strange structure. It was a collection of short steel pickets driven into the ground and then interlaced with barbed wire to form a box shape about 2 metres square and 30 centimetres high. This was the lockup for troops being punished. They were made to crawl into the structure and the entrance sealed. They could do no more than lie on the grass and were often left there overnight or for several days. Often, when they were released, they were subjected to a beating with a long cane wielded by a couple of burly troops. Those notables gave the impression of being Truong's bodyguard. This was not a form of justice found in the Australian Army!

In my opinion the establishment of the RF compound at Binh Ba did little to assist the effort to engage and destroy the Viet Cong. In many ways it was just a waste of valuable resources. I suspect that enemy activity in Binh Ba continued unhindered despite the arrival of the RF company. My tenure at Binh Ba ended when a team of AATTV advisers finally arrived unannounced with a truckload of home comforts and told us that we could return to 5 RAR. My 48 hours there had extended to over two months!

Many years later, in 2008, my wife and I toured Vietnam. We went to Vung Tau for two nights and engaged a local guide to take us to Nui Dat. Our female guide was quite knowledgeable but when we got to Binh Ba she was not familiar with the old village as it now nestles west of the new town. We eventually got a couple of local boys to guide us through the old village and through a cashew plantation to where our RF compound had been. It looked totally different. The villa had been demolished and the building materials used by the locals. The airstrip had gone and the whole area had been replanted with small rubber plants. A very bright blue shack had been erected on the base of the old villa by an old couple who were replanting the rubber. As we spoke with them, he took me around the base of the villa describing the columns of the porch and where the stairs to the upper floor had been. It was without doubt the site of my villa. 
As we posed for a photo with the couple, he declared that he had been a Viet Cong supporter, and his wife then added, 'Me too'. We shook hands and agreed that we were enemies no more. When I asked what had happened to the minefield, one of the many onlookers who had gathered around us raced off and came back with an unbelievably rusty M16 mine. After suggesting he take it well away I asked how the minefield had been cleared. The wife straightaway grabbed a stick, got down on her knees and demonstrated how she and others had prodded for the mines and neutralised the firing mechanisms - a very dicey undertaking but, perhaps, a demonstration of the futility of laying mines! However, it was great to have gone back 40 years later and reminisced about a significant chapter in my army career.

\section{Conclusion by Robert O’Neill}

Although they produced little of measurable effect on warfighting efforts in Phuoc Tuy province, the sojourns of Captains Boxall and Bade early in 5 RAR's tour were useful in that they provided the battalion with a close insight into life at the village level as well as better awareness of the machinations of disparate military and civil authorities in and around 1 ATF's bailiwick. It was a complex war, particularly at the level of South Vietnamese - US relations. Australia was a clear step down from this top layer of interaction, so it was important for us to have the direct assessments that could be derived only from the personal experience of two young officers inserted into this structure - particularly as it was a structure that did not fit together anywhere near as smoothly as its makers had intended. 
This text is taken from Vietnam Vanguard: The 5th Battalion's Approach to Counter-Insurgency, 1966, edited by Ron Boxall and Robert O'Neill, published 2020 by ANU Press, The Australian National University, Canberra, Australia.

doi.org/10.22459/VV.2019.11 